PIOTR SZKUTNIK* - ŁÓDŹ

\title{
PENSJA DZIEKANÓW \\ W KRÓLESTWIE POLSKIM DO POCZĄTKU LAT 70. XIX WIEKU. EGZEMPLIFIKACJE
}

\section{Wstęp}

Urząd dziekana w okresie staropolskim był godnością honorową ${ }^{1}$ Synody niektórych diecezji przewidziały jednak dodatkowe fundusze na rzecz dziekanów. W diecezji poznańskiej synod z 1720 r. dopuszczał przejęcie przez dziekana części opłaty karnej za poufałe współżycie kapłana ze służbą kobiecą, tj. jednej z trzech grzywien. Tenże synod, podobnie jak żmudzki z 1752 r., polecał duchownym zapisanie $\mathrm{w}$ testamencie odpowiedniej kwoty na własny pogrzeb, jako wynagrodzenie dla przeprowadzającego go dziekana. W przypadku braku takiego zapisu kuria biskupia, przy okazji aprobaty testamentu, miała zabezpieczyć odpowiednia sumę, podobnie mieli postąpić kuratorzy mienia księdza, który zmarł bez testamentu. Synod lwowski z 1765 r., w związku ze składką duchowieństwa na rzecz biskupa tj. cathedraticum, polecał wypłacać z niej każdemu dziekanowi 300 złotych polskich ${ }^{2}$. Dziekani nie mogli odbierać wynagrodzenia z okazji przeprowadzonej wizytacji. Biskup ordynariusz mógł jednak w swoim zakresie wynagrodzić służbę szczególnie zasłużonym dziekanom.

W okresie Prus Południowych (1793-1807) państwo przyznało duchownym tzw. kompetencje czyli wynagrodzenie rekompensujące zarekwirowane dobra kościelne. Pensje te były zwykle wypłacane kwartalnie z góry. Były jednak zdecydowanie niższe od dochodów dawniej osiąganych przez duchowieństwo. Rząd pruski potrącił bowiem przy ich wypłacaniu podatki, koszty administracyjne i inne,

* Piotr Szkutnik - dr historii, adiunkt w Katedrze Historii Historiografii i Nauk Pomocniczych Historii w Instytucie Historii, Uniwersytet Łódzki, e-mail: pszkutnik@poczta.onet.pl

${ }^{1}$ Artykuł bazuje na podrozdziale doktoratu zamieszczonym w pracy P. Szkutnika, Akta dziekana brzeźnickiego 1819-1867. Studium urzędu i dokumentacji, Łódź 2009, s. 143-154, mps w Archiwum Uniwersytetu Łódzkiego. Jego fragmenty zawarto w publikacji P. Szkutnika, Akta dziekana brzeźnickiego 1819-1867. Studium urzędu i dokumentacji, Łódź 2012, s. 90-92.

${ }^{2}$ Sześcioletnia korrespondencya władz duchownych z rządem świeckim Xięstwa Warszawskiego stużąca do historyi Kościoła polskiego, wyd. [I. Raczyński], [Warszawa] 1816, s. 79. 
co powodowało, że pensje wynosiły czwartą lub piątą część poprzednio pobieranych zysków z beneficjów ${ }^{3}$. Rząd pruski przejął na rzecz skarbu państwa dobra biskupów, kapituł i licznych klasztorów. Dobra ziemskie pozostały jedynie przy parafiach stanowiąc ich główne źródło dochodów ${ }^{4}$. Fundusz dla duchowieństwa o nazwie kompetencji został wprowadzony edyktem z 23 maja $1796 \mathrm{r}^{5}$

Po konfiskacie dóbr biskupich bp poznański Ignacy Raczyński w 1799 r. poprosił rząd pruski o przyznanie dziekanom odpowiedniej gaży. Dopiero w $1805 \mathrm{r}$. rząd przyznał im nieznaczny zwrot wydatków tj. 41 talarów na utrzymanie wikariusza i po 3 talary za dojazdy do poszczególnych kościołów, razem od 56 do 113 talarów, czyli od 168 do 339 marek rocznie. Rząd pruski zastrzegł sobie jednak prawo zatwierdzania nominacji dziekanów. W ciągu XIX w. kuria metropolitalna gnieźnieńska przekazywała dziekanom zwolnione beneficja w komendę tymczasową, z których pobierali oni dochody, po regulacji roszczeń spadkobierców zmarłego beneficjanta z części przysługującej mu według statutu ${ }^{6}$.

Podstawą wymiaru kompetencji w czasach Księstwa Warszawskiego były ustalenia pruskie, była ona jednak zabezpieczona na całych dobrach narodowych, a nie tylko na majątkach poduchownych ${ }^{7}$. Etat opłat duchowieństwa katolickiego na rok 1812/1813 był rozdzielony na poszczególne departamenty i wymieniał szereg pozycji, w tym pensje dziekańskie ${ }^{8}$. Przykładowo dziekan dekanatu szadkowskiego Michał Żdzenicki w 1814 r. otrzymał pensję w wysokości 119 talarów tj. 1.114 złp $^{9}$.

\section{Okres Królestwa Polskiego}

Rząd Królestwa Polskiego również przydzielił etaty dla duchowieństwa ${ }^{10}$. Od 1817 r. pensje tą wypłacała Komisja Rządowa Wyznań Religijnych i Oświe-

${ }^{3}$ Sześcioletnia korrespondencya władz duchownych z rządem świeckim Xięstwa Warszawskiego stużaca do historyi Kościoła polskiego, wyd. [I. Raczyński], [Warszawa] 1816, s. 79.

${ }^{4}$ H. Karbownik, Sprawa uposażenia i opodatkowania dochodów duchowieństwa $w$ zaborze pruskim w latach 1772-1807, PK, 39 (1996) nr 3-4, s. 257.

${ }^{5}$ A. Bossakiewicz, Fundusze duchowieństwa rzymsko-katolickiego $w$ Polsce mianowicie od 1795-1865 roku, „Biblioteka Warszawska”, 4 (164), 1881, s. 217; Rys historyczny funduszów duchowieństwa rzymsko-katolickiego w Królestwie Polskiem, „Kronika Diecezji Kujawsko-Kaliskiej” (dalej: KDKK), 9 (1915) nr 11, s. 241; A. Szelążek, Podstawy dotacji duchowieństwa katolickiego $w$ Polsce w okresie przedkonkordatowym, Torun 1947, s. 24 jako datę edyktu podaje 23 maj 1786 r.

${ }^{6}$ J. Nowacki, Archidiecezja poznańska w granicach historycznych i jej ustrój, t. 2. Dzieje archidiecezji poznańskiej, Toruń 1964, s. 335; M. Fąka, Stan prawny Kościoła katolickiego w Wielkim Księstwie Poznańskim w latach 1815-1850 w świetle prawa pruskiego. Studium prawno-historyczne, Warszawa 1975, s. 213; B. Kumor, Ustrój i organizacja Kościoła polskiego w okresie niewoli narodowej (1772-1918), Kraków 1980, s. 546; T. Ceynowa, Ziemia pogranicza, dekanat wałecki w latach 1821-1920, Radom 2004, s. 159.

${ }^{7}$ Rys historyczny funduszów duchowieństwa rzymsko-katolickiego w Królestwie Polskiem. Ciag dalszy, KDKK, 9 (1915) nr 12, s. 275.

${ }^{8}$ T. Walachowicz, Kościót katolicki w prawodawstwie Księstwa Warszawskiego, Lublin 1984, s. $156-157$.

${ }^{9}$ P. Szkutnik, Ksiadz Michat Mieczko Żdzenicki (1744-1814) proboszcz i dziekan szadkowski, „Przegląd Nauk Historycznych”, 14 (2015) nr 1, s. 184.

${ }^{10}$ Bossakiewicz, Fundusze duchowieństwa, s. 219. 
cenia Publicznego ${ }^{11}$. Państwo dotowało instytucje kościelne z dochodów z sekularyzowanych dóbr kościelnych w 1818 (tzw. funduszów supresyjnych ${ }^{12}$ ) np. konsystorze, księży emerytów czy demerytów ${ }^{13}$. Ukaz z 6/18 marca 1817 r. wprowadzający w dobrach duchowieństwa zamianę dziesięcin wytycznych na pieniądze znacznie zmniejszył dochody księży w Królestwie Polskim ${ }^{14}$.

Wypełnianie obowiązków dziekańskich w XIX w. wymagało od duchownego dużego zaangażowania. Systematyczny nadzór parafii w dekanacie, obowiązek wysyłania przynajmniej raz w miesiącu lub częściej kurendy, z czym wiązały się opłaty dla kuriera, wymagały stałych nakładów finansowych. Mimo wielu debat rządowych w czasie funkcjonowania Królestwa Polskiego odnośnie przyznania pensji dziekańskiej, według Zbigniewa Skiełczyńskiego do wyznaczenia takowej nie doszło i dziekani w archidiecezji warszawskiej pełnili swe obowiązki honorowo. By zmniejszyć koszty urzędowania wielu dziekanów upraszczało sobie pracę, polecając proboszczom przywozić księgi metrykalne poszczególnych parafii na kongregację dekanalną lub bezpośrednio do swej kancelarii, co stosowali np. dziekani brzeźniccy. Obciążenie licznymi obowiązkami i niewielkie dochody powodowały, że członkowie kapituł w archidiecezji warszawskiej w XIX w. nie byli zainteresowani funkcją dziekana, nawet gdy kanonicy rezydowali w parafii, nigdy nie pełnili urzędu dziekańskiego ${ }^{15}$.

$\mathrm{W}$ innych diecezjach dziekani pobierali uposażenie. Według instrukcji z 17 czerwca 1818 r., wydanej dla duchowieństwa przez bpa płockiego Adama Michała Prażmowskiego, pensja dziekana zależała od ilości parafii w jego dekanacie. Dla obwodu lipnowskiego i po przyłączeniu do niego dekanatu bobrownickiego pensja dziekana wynosiła 940 zł, dla obwodu płockiego - 1140 zł, dla obwodu mławskiego - $980 \mathrm{zl}$, dla przasnyskiego $-580 \mathrm{zl}$, ostrołęckiego - $460 \mathrm{zl}$, pułtuskiego - $700 \mathrm{zł}$. Dziekani dobrze pełniący swe obowiązki mieli mieć ponadto pierwszeństwo do otrzymania prałatur i kanonii kolegiaty pułtuskiej ${ }^{16}$.

W diecezji augustowskiej (sejneńskiej) w XIX w. kapłani uchylali się od przyjęcia obowiązków dziekana. Powodem tego była m.in. niska pensja ${ }^{17}$. Jeden z członków tamtejszej kapituły katedralnej uważał wręcz za uwłaczające jego statusowi, ,aby miał się szargać po stajniach i oborach pilnując formalności wskaza-

${ }^{11}$ Kumor, Ustrój i organizacja Kościoła, s. 687.

${ }^{12}$ J. Gacki, Benedyktyński klasztor świętego krzyża na Łysej Górze, Warszawa 1873, s. 329-330. Dekret supresyjny (kasacyjny) wydano 17 kwietnia 1819 r. Zob.: P.P. Gach, Kasaty zakonów na ziemiach dawnej Rzeczpospolitej i Ślaska 1773-1914, Lublin 1984, s. 105-110.

${ }^{13}$ Kumor, Ustrój i organizacja Kościoła, s. 242; W. Wójcik, Domy demerytów w Królestwie Polskim (1836-1885), PK, 25 (1981) nr 3-4, s. 225.

${ }^{14}$ A. Szelążek, Podstawy dotacji duchowieństwa katolickiego w Polsce w okresie przedkonkordatowym, Toruń 1947, s. 40.

${ }^{15}$ Z. Skiełczyński, Archidiecezja warszawska w latach 1818-1830, „Studia z Historii Kościoła w Polsce", 4 (1978) s. 111-112.

${ }^{16}$ J. Lupiński, Dziekani okręgowi w diecezji wigierskiej i diecezji augustowskiej czyli sejneńskiej, PK, 49 (2006) nr 1-2, s. 196-198.

${ }^{17}$ W. Jemielity, Obsada stanowisk kościelnych w Królestwie Polskim do powstania styczniowego, PK, 43 (2000) nr 3-4, s. 384. 
nych przepisami, gdy może to wykonywać zwykły kapłan”. W 1821 r. dziekan łomżyński otrzymywał 390 zł, tykociński, wąsoski, wiski i wysokomazowiecki po 300 zł. Wysokość gaży była uzależniona również od ilości parafii w dekanacie. Fundusz pochodził ze zlikwidowanych przez rząd instytucji kościelnych. W 1826 roku komisja rządowa określiła wysokość uposażenia na 30 zł od jednego kościoła w dekanacie ${ }^{18}$.

Pobierane wynagrodzenie było tak niskie, iż dziekan dekanatu kalwaryjskiego w 1835 r. uważał, że wystarczało jedynie na materiały kancelaryjne. W repartycji litewskiej tej diecezji dziekan największego dekanatu augustowskiego pobierał $420 \mathrm{zł}$ rocznie, a w najmniejszych: łoździejskim i sejneńskim - po 268 zł. W następnych latach pensja nie uległa zapewne większym zmianom. Jej wysokość cały czas była uzależniona od ilości parafii w dekanacie ${ }^{19}$.

W diecezji kujawsko-kaliskiej dziekani również pobierali pensję. Była ona wypłacana przez władze państwowe, co pozwalało jej dysponentowi na dokonywanie potrąceń lub rewindykacji należności w przypadku jakichkolwiek zobowiązań finansowych odbierającego wynagrodzenie. Sytuacje, w której pensje dziekana potraktowano jako zastaw przedstawia wezwanie skierowane do dziekana brzeźnickiego z 27 września 1820 r. dotyczące nadzoru nad szkolnictwem ${ }^{20}$. Komisarz zlecił dziekanowi w swym dekanacie sprzedaż przekazanych mu 167 egzemplarzy książek dla szkół elementarnych. Dziekan miał urządzić u siebie skład wspomnianych książek, a zabezpieczeniem dla komisarza miała być pensja dziekana ${ }^{21}$.

Pensję dziekańską wypłacała kasa z danej jednostki administracji świeckiej. W piśmie z 28 grudnia 1825 r. wspomniał o tym bp kujawsko-kaliski Józef Szczepan Koźmian przesyłając Konsystorzowi Generalnemu dyplomy nominacyjne na urzędy dziekańskie dla Macieja Drozdowskiego na dziekana konińskiego i Tomasza Stefanowskiego na dziekana kolskiego. Biskup polecił konsystorzowi kaliskiemu, by zawiadomił nominowanych,

iż kompetencya dziekańska dla każdego resp: dziekana przypadająca od d. 1 stycznia r. 1826 tymże z kassy województwa kaliskiego wypłacana będzie, o co w dniu dzi[si]eyszym przełożenie nasze do Kommissyi Rządowey Wyznań Religijnych i Oświecenia Publicznego uczyniliśmy ${ }^{22}$.

Podobne ,przełożenie uczynił” ten biskup diecezji do wspomnianego ministerstwa w sprawie pobierania kompetencji dziekańskich od 1 stycznia 1826 r., przez Michała Zagalskiego proboszcza parafii w Pajęcznie mianowanego na dziekana brzeźnickiego, o czym poinformował go Konsystorz Foralny Piotrkowski

${ }^{18}$ Lupiński, Dziekani okręgowi w diecezji, s. 202-203.

${ }^{19}$ W. Jemielity, Diecezja augustowska czyli sejneńska w latach 1818-1872, Lublin 1972, s. 194.

${ }^{20}$ Wezwanie to komisarz obwodu piotrkowskiego oparł na reskrypcie komisji wojewódzkiej z

21 sierpnia 1820 r. wynikającym z reskryptu Komisji Rządowej Wyznań Religijnych i Oświecenia Publicznego z 29 stycznia $1820 \mathrm{r}$.

${ }^{21}$ Archiwum Archidiecezji Częstochowskiej im. ks. Walentego Patykiewicza w Częstochowie (dalej: AACz), Księgi Dziekańskie, sygn. KD 25, s. 291-293.

${ }^{22}$ Archiwum Diecezjalne we Włocławku (dalej: ADWł), Akta diecezji kujawsko- kaliskiej, Akta Konsystorza Generalnego Kaliskiego. Zasób kaliski, sygn. III 13, dok. nr 943. 
7 stycznia 1826 r. przesyłając dyplom nominacji ${ }^{23}$. Po śmierci dziekana brzeźnickiego M. Zagalskiego administrator diecezji kujawsko-kaliskiej 1 lutego $1833 \mathrm{r}$. poinformował Komisję Województwa Kaliskiego o wyznaczeniu jego następcy Andrzeja Mulzowa. Komisja ta była wówczas dysponentem pensji dziekańskiej. Administrator poprosił zatem komisję wojewódzką o wypłatę kompetencji dziekańskiej A. Mulzowowi za okres od dnia zgonu poprzednika ${ }^{24}$.

Księża nie zawsze regularnie, tj. w odpowiednim czasie, zgłaszali się do kas skarbowych po kompetencje czy też pensje roczne. Duchowni byli zobligowani odbierać swoje wynagrodzenie zaraz po zakończeniu danego kwartału, termin ten nie był przez nich zawsze przestrzegany, o czym donosiła administracja państwowa hierarchom kościelnym. Komisja Rządowa Spraw Wewnętrznych, Duchownych i Oświecania Publicznego reskryptem z 7 marca 1834 r. poleciła, by każdy z duchownych zgłaszał się do odpowiedniej kasy po odbiór pensji lub kompetencji zaraz po zakończonym kwartale, a najpóźniej 8 dni od jego zakończenia. Odbiór wynagrodzenia po tym terminie miał być utrudniony, pensja przepadała po upływie roku, ,gdy obrachunki kassowe zamknięte zostaną," 25 .

Pensja dziekańska była wówczas również wypłacana kwartalnie, świadczy o tym wzór pokwitowania odbioru pensji dziekańskiej, zapisany na pierwszej stronie dziennika kancelaryjnego dziekana dekanatu tuszyńskiego:

Wzór zło:[tych] pol.[skich] 105. Wyraźnie złotych polskich sto pięć pensyi mnie iako dziekanowi tuszyńskiemu z etatu województwa kaliskiego należącey się za kwartał czwarty v.[el] pierwszy, to iest od dnia pierwszego października do ostatniego grudnia, tysiąc ośmset trzydziestego trzeciego roku, z kassy główney województwa kaliskiego odebrałem, z których odebranych kwituję. Dan w Tuszynie dnia 15 sty.[cznia] 1834 r. X.[iądz] B.[orzęcki] D.[ziekan] F.[oralny] T. [uszyński] /: dać pieczęć dziekańską:/26.

Znając ww. wysokość pensji kwartalnej można obliczyć, iż dziekan tuszyński pobierał rocznie $420 \mathrm{złp}$. (tj. $63 \mathrm{rs.})^{27}$ wynagrodzenia. Dla porównania w $1837 \mathrm{r}$. dziekan częstochowski Adam Sadowski otrzymywał ok 250 złp. (37 1/2 rs.) pensji dziekańskiej, przy czym jako proboszcz Kłobucka posiadający jednocześnie dochody z innych prebend otrzymywał ponadto łącznie 2754 złp. ${ }^{28}$ Dziekani będący proboszczami małych parafii posiadali mniejsze pobory, pośrednio świadczy o tym wartość ruchomości przez nich zgromadzonych ${ }^{29}$. W świetle protokołu zdawczo-odbiorczego z 11 maja 1846 r. pensja dziekana brzeźnickiego była wyż-

${ }^{23}$ AACz, Księgi Dziekańskie, sygn. KD 28, s. 285.

${ }^{24}$ ADWł, Akta diecezji kujawsko-kaliskiej, Archiwum Konsystorza Generalnego Włocławskiego, Akta personalne, Akta ks. Zagalskiego Michała (1773-1832), k. 2v.

${ }^{25}$ ADWł, Akta diecezji kujawsko-kaliskiej, Akta Konsystorza Generalnego Kaliskiego. Zasób kaliski, sygn. II 11, dok. nr 217.

${ }^{26}$ Archiwum Parafialne w Dłutowie, [dziennik dziekana dekanatu tuszyńskiego], k. nlb.

${ }^{27}$ W latach 1816-1841 wartość 1 rubla srebrnego (rs.) wynosiła 6 i 2/3 zł polskiego (złp.). Zob. I. Ihnatowicz, A. Biernat, Vademecum do badań nad historia XIX i XX wieku, Warszawa 2003, s. 91.

${ }^{28} \mathrm{AACz}$, Księgi Konsystorskie, KK 167, s. 279.

${ }^{29}$ Józef de Sotro dziekan dekanatu sieradzkiego, proboszcz parafii Stolec zmarły w $1828 \mathrm{r}$. według licytacji z 19 listopada 1828 r. posiadał plony rolne wartości 1278 złp. i 22,5 gr. oraz ru- 
sza, ustalono ją bowiem na 480 złp. tj. 72 rs. rocznie. Dziekan ten otrzymywał pensję co kwartał z kasy właściwego powiatu w kwocie 120 złp. czyli 18 rs., po okazaniu kwitu uwierzytelnionego przez wójta gminy i zaawizowanego przez naczelnika powiatu ${ }^{30}$. O nominacji dziekańskiej konsystorz zawiadamiał bowiem komisję wojewódzką, a ta zobowiązywała kasę danego powiatu do wypłaty pensji dziekanowi ${ }^{31}$.

Zależność finansowa dziekanów od władz cywilnych powodowała, iż stawali się oni wykonawcami ich woli. Finansową zależność przypominała dziekanom komisja rządowa. $Z$ tytułu wypłacania pensji władze starały się wykorzystywać dziekana do zlecanych przez siebie zadań, co było związane z usytuowaniem tego urzędu na styku władz świeckich i kościelnych. W reskrypcie z 17/29 października 1856 r. skierowanym do administratora diecezji kujawsko-kaliskiej Komisja Rządowa Spraw Wewnętrznych i Duchownych zawarła odpowiedź na ,przełożenie" tegoż administratora z 7/19 kwietnia 1856 r. dotyczące braku możliwości szybkiego przeprowadzenia przez dziekanów nowego spisu funduszów duchownych. Administrator proponował, by do przeprowadzenia spisów wyznaczyć w miejsce dziekanów specjalnych komisarzy duchownych z odpowiednim wynagrodzeniem za tą czynność. Komisja rządowa odpowiedziała:

gdy spisem tym według przyjętej zasady zając się mają głównie dozory kościelne do składu których należą z urzędu dziekani właściwi -gdy nadto ci ostatni za czynności dziekańskie pobierają ze skarbu wynagrodzenie [...], gdy wreszcie dziekani z urzędu swego obowiązani są odbywać periodyczne wizyty kościoła i ściśle sprawdzać na miejscu ich inwentarze fundi instructi, a zatem i czynność sporzędzenia nowych spisów tem łatwiej i skuteczniej jednocześnie dopełnić mogą gdy na koniec w tych miejscach gdzieżby dziekani właściwym dekanatów, czynnością spisu dla jakichkolwiek przyczyn sami zająć się nie mogli, instrukcya o tychże spisach w paragrafie 6tym dozwala użycia w ich zastępstwie innych osób duchownych przez wladzę dyecezalną przeznaczonych, użycie przeto do spisu oddzielnych kommissarzy duchownych za nieodzowne poczytane być nie może ${ }^{32}$.

Na mocy ukazów carskich z 27 października/8 listopada 1864 r. i 14/26 grudnia 1865 r., administracja państwowa przejęły dobra Kościoła katolickiego, przyznając jednocześnie pensje dla dostojników kościelnych ${ }^{33}$. W wyniku konfiskaty ziemi w Królestwie Polskim w 1866 r. $^{34}$ areał pozostający w posiadaniu poszcze-

chomości wartości 1696 złp. i 7 gr. Zob.: Archiwum Państwowe w Łodzi oddział w Sieradzu, Akta notariusza Antoniego Pstrokońskiego, sygn. 20 (1828 r.), k. 391-394.

${ }^{30} \mathrm{AACz}$, Księgi Dziekańskie, sygn. KD 32, s. 351.

${ }^{31}$ Jemielity, Obsada stanowisk kościelnych, s. 384.

${ }^{32}$ AACz, Księgi Dziekańskie, sygn. KD 40, s. 451-452.

${ }^{33}$ Dziennik Praw Królestwa Polskiego, t. 62, [Warszawa 1864], s. 406-419; Dziennik Praw Królestwa Polskiego, t. 63, [Warszawa 1865], s. 375-377; W. Jemielity, Upaństwowienie majątków kościelnych w powiatach łomżyńskim i mazowieckim po powstaniu styczniowym, „Studia Łomżyńskie", 5 (1995) s. 5-14.

${ }^{34}$ S. Piątkowski, Gospodarstwo folwarczne i chtopskie w dobrach proboszczowskich Królestwa Polskiego w pierwszej połowie XIX wieku (przykład rejonu środkowej Wisły), „Studia Sandomierskie", 10 (2003) s. 53. 
gólnych parafii ograniczono do 6 mórg ziemi ${ }^{35}$. W wyniku ukazu carskiego z 14/26 grudnia 1865 r. parafie podzielono na trzy klasy. Parafie dziekańskie w Królestwie Polskim zaliczono do drugiej klasy parafii, których rządca otrzymywał 400 rs. ${ }^{36}$

Instytucją dysponującą wówczas środkami wypłacanymi w ramach pensji dziekańskich był Rząd Gubernialny Warszawski. W piśmie do tegoż rządu z 8 maja 1865 r. Konsystorz Generalny Kaliski prosił adresata (poprzednio 16 stycznia 1865 r.), by polecił kasie powiatu kaliskiego wypłacić zaległą pensję, należącą się dziekanowi dekanatu stawiszyńskiego za czwarty kwartał $1864 \mathrm{r}^{37}$

Pensja była wypłacana przez władze cywilne, stąd też w przypadku jakichkolwiek wątpliwości, domagały się one przedstawiania dokumentów potwierdzających objęcie urzędu dziekańskiego, wystawionych przez komisję rządową i podania daty, od której należało się wynagrodzenie. W piśmie z 16/28 października 1865 r. naczelnik powiatu sieradzkiego domagał się tych informacji od Konsystorza Generalnego Kaliskiego:

Dla wyasygnowania zaległej pensyi dziekańskiej za dwa półrocza 1863 r. księdzu Pyszyńskiemu dziekanowi dekanatu lutomierskiego Rząd Gubernialny Warszawski reskryptem z dnia 28 sierpnia/9 września r.b. No 38079/8681 zażądał wiadomości od jakiego czasu ksiądz Pyszyński sprawuje urząd dziekana i kiedy przez kommissyą rządową był zatwierdzony, mam honor więc wezwać uprzejmie konsystorz o udzielenie tej wiadomości, o ile może być najspieszniej, gdyż rząd gubernialny zastrzegł, że w razie najmniejszej zwłoki pensya ta na oszczędność skarbu odpisaną będzie ${ }^{38}$.

Informacje o duchownych pełniących obowiązki dziekana, a zatem o tym komu należy wypłacać pensję dziekańską, były dostarczane komisji rządowej w postaci corocznych raportów o obsadzie urzędów kościelnych. Dowodzi tego dekretacja bpa kujawsko-kaliskiego Jana Michała Marszewskiego z 31 grudnia 1865 r. skierowana do Konsystorza Generalnego Kaliskiego w sprawie pensji dziekana, w której biskup dziwił się konieczności dostarczania dodatkowych dowodów na pełnienie urzędu dziekana przez ww. Teodora Pyszyńskiego.

Tenże x. Pyszyński przedstawiany bywa corocznie Kommissyi Rządowey Spraw Wew:[nętrznych] i Duch[ownych] w charakterze dziekana dekanatu lutomierskiego w wykazach i katalogach duchowieństwa dyecezyi kujawsko -kaliskiej, która taż kommissyia rządowa przyjmuie i zatwierdza i dotąd o nim żadney nie zrobiła kwestyi ${ }^{39}$.

W okresie przejściowym, po powstaniu styczniowym a przed wprowadzeniem dekanatów w granicach powiatów, rząd również wypłacał pensje dziekańskie. Były one w takiej wysokości jak wcześniej wypłacane gaże. Kwestie pensji

${ }^{35}$ W naszych sprawach. W sprawie uposażenia duchowieństwa, KDKK, 13 (1919) nr 4, s. 124; J. Lubelski, Sprawa uposażenia duchowieństwa, KDKK, 14 (1920) nr 10, s. 302.

${ }^{36}$ W. Jemielity, Czwarta część majątku po zmarłych proboszczach w Królestwie Polskim, PK, 37 (1994) nr 1-2, s. 261.

${ }^{37}$ ADWł, Akta diecezji kujawsko- kaliskiej, Akta Konsystorza Generalnego Kaliskiego. Zasób kaliski, sygn. III 13, dok. nr 564.

${ }^{38}$ Tamże, dok. nr 14994.

${ }^{39}$ Tamże, dok. nr 1603. 
dziekańskich północnej części diecezji kujawsko-kaliskiej tj. w oficjalacie kaliskim, w tym okresie szczegółowo omawia reskrypt Komisji Rządowej Spraw Wewnętrznych i Duchowieństwa z 13/25 lipca 1866 r. skierowany do biskupa kujawsko-kaliskiego.

Na zasadzie art. 7 naj.[wyższego] ukazu z d. 14/26 grud.[nia] 1865 r. o duchowieństwie świeckiem ma nastąpić nowe rozgraniczenie probostw na dekanaty, liczące na każdy powiat jeden dekanat, poczem dziekani tytułem dodatku do uposażenia swego mają otrzymywać rocznie po r[ubli] sr.[ebrem] 150. Ponieważ dotąd z powodu spodziewanego podziału królestwa na 85 powiatów nie nastąpił jeszcze nowy rozdział probostw na dekanaty przeto, aby nie pozbawiać dziekanów wynagrodzenia za pełnione przez nich obowiązki, kommissya rządowa postanowiła przyznać im za rok bieżący dotychczasowe wynagrodzenie. Jakoż w tym celu komissya rządowa poleciła rządowi gubernialnemu, ażeby przypadające za rok bieżący wynagrodzenie:

1. dziekanowi kaliskiemu r[ubli] sr.[ebrem] 67, kop[iejek] 50

2. kolskiemu

45

3. konińskiemu

81

4. lutomirskiemu 50

5. sompolińskiemu

49

6. sieradzkiemu

7. słupeckiemu

8. stawiszyńskiemu

9. stawskiemu

10. szadkowskiemu

81

11. uniejowskimu

63

12. wieruszowskiemu

wypłacone było $\mathrm{z}$ właściwej kassy w ratach tercyałowych $\mathrm{z}$ dołu za kwitami resp. dziekanów poświadczonemi przez władzę dyecezalną. Zarazem komissya rządowa nadmieniła: a. że gdyby który z dziekanów nie sprawował swych obowiązków przez caly tercyał, wypłata dla niego wynagrodzenia powinna nastąpić jedynie tylko za ten przeciąg czasu, przez który był czynnym a reszta należności dla niego wyasygnowanej pozostaie w skarbie. b. że wypłata wynagrodzenia po r[ubli] sr.[ebrem] 150 zapewnionego dziekanom art. 7 ukazu naj. [wyższego] zadysponowaną zostanie dopiero w ten czas, jak nastąpi wskazane tymże artykułem rozgraniczenie dekanatów ${ }^{40}$.

O ww. postanowieniu komisji rządowej biskup kujawsko-kaliski J. M. Marszewski powiadomił 28 lipca 1866 r. Konsystorz Generalny Kaliski, by poinformował o tym dziekanów oficjalatu kaliskiego ${ }^{41}$.

$\mathrm{Na}$ podstawie ww. reskryptu z 13/25 lipca $1866 \mathrm{r}$. w oficjalacie piotrkowskim przyznano na 1866 r. następujące zarobki: dziekanowi brzeźnickiemu 72 rs., częstochowskiemu 67 rs. 50 kop., krzepickiemu 63 rs., piotrkowskiemu 63 rs., radom[szczań]skiemu 76 rs. 50 kop., tuszyńskiemu 63 rs., wieluńskiemu 76 rs. 50 kop. ${ }^{42}$

${ }^{40}$ Tamże, dok. nr 2278/4221.

${ }^{41}$ Tamże, dok. nr 1051.

${ }^{42}$ Archiwum Archidiecezjalne w Łodzi (dalej: AAŁ), Akta Kosystorza Foralnego Piotrkowskiego, sygn. 16, k. nlb; W. Wlaźlak, Organizacja i dziatalność Konsystorza Foralnego Piotrkow- 
Konsystorz Foralny Piotrkowskim przesyłał podległym sobie dziekanom pisma o ww. reskrypcie. Dnia 21 sierpnia 1866 r. zawiadomił Józefa Piotrowskiego pełniącego obowiązki dziekana brzeźnickiego, iż do czasu wprowadzenia dekanatów w granicach powiatów, rząd gubernialny otrzymał upoważnienie dotyczące jego wynagrodzenia. Za pośrednictwem kasy powiatowej rząd miał wypłacić J. Piotrowskiemu za pełnienie obowiązków dziekana w każdy tercyat ww. pensję wynoszącą rocznie 72 rs. ,za kwitem przez władzę duchowną poświadczonym”. Kwota wynagrodzenia pobierana przez dziekana brzeźnickiego nie zmieniła się zatem od 1846 r. ${ }^{43}$ Zaświadczenie, na podstawie którego J. Piotrowski jako dziekan i proboszcz miał pobierać pensję, zgodnie z poleceniem Konsystorza Foralnego Piotrkowskiego z 13/25 maja 1867 r. musiało być „ulegalizowane” przez burmistrza miasta. Konsystorz oparł polecenie na reskrypcie zawiadamiającym o wyasygnowaniu pensji dla duchowieństwa ${ }^{44}$.

Pojawiały się jednak problemy z odbiorem przydzielonego wynagrodzenia. W piśmie z 15 listopada 1866 r. skierowanym do Konsystorza Generalnego Kaliskiego dziekan dekanatu szadkowskiego Michał Jarmicki doniósł o braku możliwości pobrania pensji zagwarantowanej ww. reskryptem komisji rządowej.

Reskryptem prześwietnego konsystorza jeneralnego z dnia jeszcze 1. sierpnia rb. No 969 łaskawie zawiadomiony zostałem o przyznanem dla dziekanów wynagrodzeniu $\mathrm{w}$ stosunku dawniejszej pobieranej płacy. Tymczasem tak kassa powiatu jak i naczelnik jego zgłaszającemu się w odbiór powyższego wynagrodzenia odpowiadają: iż dotąd $\mathrm{w}$ tej mierze nieodebrani z góry żadnej dyspozycyi i że przed Nowym Rokiem potrzeba się za pośrednictwem prześwietnego konsystorza odnieść do Rządu Gubernialnego Warszawskiego gdzie przedmiot o jaki idzie zalega, bo po Nowym Roku fundusz ma ad quaestionis wskazany odesłanym zostanie.

W tej sprawie Konsystorz Generalny Kaliski skierował 27 listopada 1866 r. prośbę do Rządu Gubernialnego Warszawskiego ${ }^{45}$.

Dziekan tuszyński Stanisław Tański w pismach 9 grudnia 1866 r. i 8 maja 1867 r. komunikował Konsystorzowi Foralnemu Piotrkowskiemu, iż jak dotąd nie otrzymał obiecanej pensji z kasy powiatu piotrkowskiego. Wynagrodzenia za ten okres nie odebrali również dziekan radom[szczań]ski i brzeźnicki. Kasa powiatu otrzymała bowiem polecenie wypłaty pensji jedynie dziekanowi piotrkowskiemu. Wobec powyższego konsystorz 20 grudnia 1866 r. i 10 maja 1867 r. poprosił biskupa diecezji o wyjednanie w ministerstwie dyspozycji na wypłatę uposażenia wspomnianym dziekanom ${ }^{46}$.

Klemens Skupieński administrator diecezji kujawsko-kaliskiej dopiero 14 stycznia 1868 r. poinformował Konsystorz Foralny Piotrkowski, iż właściwie rządy gubernialne otrzymały polecenie, by zarządzić wypłatę wynagrodzenia za

skiego w latach 1819-1918, Częstochowa 2004, s. 157.

${ }^{43} \mathrm{AACz}$, Księgi Dziekańskie, sygn. KD 45, s. 217.

${ }^{44} \mathrm{AACz}$, Księgi Dziekańskie, sygn. KD 52, s. 173.

${ }^{45}$ ADWł, Akta diecezji kujawsko- kaliskiej, Akta Konsystorza Generalnego Kaliskiego. Zasób kaliski, sygn. III 13, dok. nr 93.

${ }^{46}$ AAŁ, Akta Kosystorza Foralnego Piotrkowskiego, sygn. 16, k. nlb. 
1867 r. duchownym pełniącym obowiązki dziekanów w diecezji kujawsko-kaliskiej według „,dawniejszej zasady t.j. licząc po rsr. 4 kop. 50 za każdy kościół parafialny znajdujący się w teraźniejszym dekanacie"47. Pensję dziekańską w wysokości 150 rs. podaną w ukazie z 14/26 grudnia $1865 \mathrm{r}^{48}$, wprowadzono dopiero po utworzeniu dekanatów powiatowych 1 stycznia $1868 \mathrm{r}$.

Pensja dziekana stanowiła jedynie skromne uzupełnienie ówczesnego dochodu pobieranego przez proboszcza, który de facto była podstawą utrzymania dziekana. W piśmie z 30 marca/11 kwietnia 1867 r. naczelnik powiatu radomszczańskiego na podstawie reskryptu Rządu Gubernialnego Piotrkowskiego z 25 marca/6 kwietnia 1867 r. zażądał od dziekana brzeźnickiego przesłania, według załączonego wzoru, wykazu duchownych. Wykaz miał być sporządzony z powodu planowanej wypłaty duchowieństwu pensji przed końcem tercjału b.r. i miał zawierać zmiany na stanowiskach od $1 / 13$ stycznia do $18 / 30$ marca $1867 \mathrm{r}^{49}$ Sporządzona na tej podstawie przez dziekana lista imienna duchowieństwa dekanatu zawiera m.in. dane o pensji pobieranej przez samego p.o. dziekana J. Piotrowskiego. J. Piotrowski jako proboszcz parafii Brzeźnica powołany na to stanowisko na mocy postanowienia Rady Administracyjnej z 31 maja/12 czerwca 1863 r. otrzymał 400 rs. za 1866 r. do dnia 13 stycznia 1867 r. ${ }^{50}$

$\mathrm{Z}$ pensji dziekańskiej mogły być potrącane kwoty na różne wydatki. Konsystorz Foralny Piotrkowski 11 maja 1867 r. poinformował dziekana J. Piotrowskiego, na podstawie reskryptu biskupa diecezji z 1 maja 1867 r., iż komisja rządowa pismem z 6/18 grudnia 1866 r. oświadczyła, iż nie anuluje obowiązku prenumeraty przez duchownych dziennika gubernialnego. Należność za ww. periodyk miała być potrącana z pensji duchownych wypłacanej przez skarb państwa. Opłata za prenumeratę ww. dziennika wynosiła 1 rs. 80 kop. rocznie oraz 18 kop. za przesyłkę ${ }^{51}$.

\section{Zakończenie}

Łączne zestawienia dotyczące wysokości pensji dziekańskich znalazły odzwierciedlenie w literaturze przedmiotu. Paweł Wolnicki ustalił, iż w latach 18191847 rządowa pensja dziekańska w Królestwie Polskim wynosiła 250 złp. (37 1/2 rs.), natomiast w latach 1848-1865 odpowiednio 100 rs. (666 złp.), a od $1866 \mathrm{r}$. 150 rs. (1000 złp. $)^{52}$ Według ks. Władysława P. Wlaźlaka takiej właśnie wysokości pensje $\mathrm{z}$ funduszu kompetencyjnego pobierali w diecezji kujawsko-kaliskiej w podanych zakresach lat dziekani: brzeźnicki, radomszczański, krzepicki i tuszyński pracujący w Konsystorzu Foralnym Piotrkowskim ${ }^{53}$. Dane ze źródeł po-

${ }^{47}$ AAŁ, Akta Kosystorza Foralnego Piotrkowskiego, sygn. 16, k. nlb.

${ }^{48}$ Szelążek, Podstawy dotacji duchowieństwa, s. 95.

${ }^{49}$ AACz, Księgi Dziekańskie, sygn. KD 45, s. 243-244.

${ }^{50}$ Tamże, s. 245-247.

${ }^{51}$ AACz, Księgi Dziekańskie, sygn. KD 49, s. 1039.

${ }_{52}$ P. Wolnicki, Kancelarie dziekańskie w Królestwie Polskim, „Archeion”, 109 (2006) s. 166; tenże, Urzad, kancelaria i akta dziekańskie w okresie Królestwa Polskiego (1818-1918). Studium administracyjno-kancelaryjno-archiwalne, Częstochowa 2011, s. 124.

${ }^{53}$ Wlaźlak, Organizacja i działalność, s. 144-148, 153-154. 
zyskane przez autora sugerują jednak zróżnicowanie wysokości pensji nie tylko w danych okresach, ale przede wszystkim w zależności od wielkości dekanatu (liczby znajdujących się w nim parafii). Od lat 20. XIX w., zapewne w całym Królestwie Polskim, obowiązywała stawka wynagrodzenia wynosząca 4 rs. i 50 kop. (30 złp.) od jednej parafii w dekanacie. Potwierdzają to szczególnie wyżej omówione wyniki badań W. Jemielitego i J. Łupińskiego, według których pensja dziekańska w latach 1818-1835 wynosiła od 268 złp. (40 1⁄4 rs.) do 1140 złp. (171 rs.) oraz dane źródłowe z diecezji kujawsko kaliskiej, według których wynagrodzenie dziekańskie w latach 60. XIX w. wynosiło od 45 (300 złp.) do 81 rs. (539 $1 / 2$ złp.).

Pensje stanowiły kwoty uzupełniające budżet dziekana opierający się głównie na poborach pochodzących z zarządzanej przez niego jednocześnie parafii oraz innych dodatkowo administrowanych. Jeden $z$ wyżej cytowanych przykładów dowodzi, że pensja dziekańska mogła stanowić nawet zaledwie 1/10 całego dochodu duchownego. Samo uposażenie dziekana było stosunkowo niskie w porównaniu z poborami innych urzędników. Burmistrz miasta Piotrkowa zarabiał wielokrotnie więcej niż ówcześni dziekani, gdyż jego roczna pensja w 1825 r. wynosiła 3000 złp. $\left(4501 \frac{1}{2} \text { rs. }\right)^{54}$. Pobory zamożniejszych dziekanów są zbliżone do słabo wówczas uposażonych pracowników oświaty. Nauczyciel szkoły elementarnej w Królestwie Polskim w 1817 r. otrzymywał średnio 700 złp. (105 rs.) w latach 40. i 50. otrzymywał średnio 60 rs. $(400 \text { złp. })^{55}$

Pensja wypłacana przez administrację zaborczą stała się instrumentem nacisku na duchowieństwo powodując jednocześnie, że duchowni na rządowym uposażeniu zyskali jeden z przymiotów cechujących typowego urzędnika. Hierarchia kościelna została tym samym włączona w XIX-wieczny system biurokratyczny ${ }^{56}$. Pobierający pensję duchowny był zależny od dysponenta co powodowało, iż musiał on wykonywać zadania również świeckich przełożonych.

Słowa kluczowe: Historia Kościoła w Polsce w XIX w., dziekan, Królestwo Polskie, zabór rosyjski, pensja

${ }^{54}$ K. Łapiński, Organizacja władz miejskich Piotrkowa w latach 1809-1867 i ich pozostałość aktowa, „Rocznik Łódzki”, 39 (1989) s. 29.

${ }^{55} \mathrm{M}$. Bogus, Nędza z bida w parze ida. O sytuacji nauczycieli w XIX wieku, w: Język-SzkołaPrzestrzeń jako determinanty rozwoju kultury Śląska Cieszyńskiego, red. M. Bogus, Czeski Cieszyn 2012, s. 90-91.

${ }^{56}$ H. Izdebski, Historia administracji, Warszawa 2000, s. 36-38. 


\section{BIBLIOGRAFIA}

\section{Źródła}

Archiwum Archidiecezjalne w Łodzi, Akta Kosystorza Foralnego Piotrkowskiego, sygn. 16.

Archiwum Archidiecezji Częstochowskiej im. ks. Walentego Patykiewicza w Częstochowie, Księgi Dziekańskie, sygn. KD 25, KD 28, KD 32, KD 40, KD 45, KD 45, KD 49, KD 52; Księgi Konsystorskie, KK 167.

Archiwum Diecezjalne we Włocławku, Akta diecezji kujawsko- kaliskiej, Akta Konsystorza Generalnego Kaliskiego. Zasób kaliski, sygn. II 11, III 13; Archiwum Konsystorza Generalnego Włocławskiego, Akta personalne, Akta ks. Zagalskiego Michała (17731832).

Archiwum Państwowe w Łodzi oddział w Sieradzu, Akta notariusza Antoniego Pstrokońskiego, sygn. 20 (1828 r.).

Archiwum Parafialne w Dłutowie, [dziennik dziekana dekanatu tuszyńskiego].

Dziennik Praw Królestwa Polskiego, t. 62, [Warszawa 1864].

Dziennik Praw Królestwa Polskiego, t. 63, [Warszawa 1865].

\section{Opracowania}

Bogus M., Nędza z bidą w parze idą. O sytuacji nauczycieli w XIX wieku, w: JęzykSzkoła- Przestrzeń jako determinanty rozwoju kultury Śląska Cieszyńskiego, red. M. Bogus, Czeski Cieszyn 2012, s. 57-100.

Bossakiewicz A., Fundusze duchowieństwa rzymsko-katolickiego w Polsce mianowicie od 1795-1865 roku, „Biblioteka Warszawska”, 4 (164) 1881.

Ceynowa T., Ziemia pogranicza, dekanat wałecki w latach 1821-1920, Radom 2004.

Fąka M., Stan prawny Kościoła katolickiego w Wielkim Księstwie Poznańskim w latach 1815-1850 w świetle prawa pruskiego. Studium prawno-historyczne, Warszawa 1975.

Gach P.P., Kasaty zakonów na ziemiach dawnej Rzeczpospolitej i Śląska 1773-1914, Lublin 1984.

Gacki J., Benedyktyński klasztor świętego krzyża na Łysej Górze, Warszawa 1873.

Ihnatowicz I., Biernat A., Vademecum do badań nad historią XIX i XX wieku, Warszawa 2003.

Izdebski H., Historia administracji, Warszawa 2000.

Jemielity W., Czwarta część majątku po zmarłych proboszczach w Królestwie Polskim, „Prawo Kanoniczne”, 37 (1994) nr 1-2, s. 259-268.

Jemielity W., Diecezja augustowska czyli sejneńska w latach 1818-1872, Lublin 1972.

Jemielity W., Obsada stanowisk kościelnych w Królestwie Polskim do powstania styczniowego, „Prawo Kanoniczne”, 43 (2000) nr 3-4, s. 351-385.

Jemielity W., Upaństwowienie majątków kościelnych w powiatach łomżyńskim i mazowieckim po powstaniu styczniowym, „Studia Łomżyńskie”, 5 (1995) s. 5-14.

Karbownik H., Sprawa uposażenia i opodatkowania dochodów duchowieństwa w zaborze pruskim w latach 1772-1807, „Prawo Kanoniczne”, 39 (1996) nr 3-4, s. 243-268.

Kumor B., Ustrój i organizacja Kościoła polskiego w okresie niewoli narodowej (17721918), Kraków 1980.

Lubelski J., Sprawa uposażenia duchowieństwa, „Kronika Diecezji Kujawsko-Kaliskiej”, 14 (1920) nr 10, s. 302-306.

Łapiński K., Organizacja władz miejskich Piotrkowa w latach 1809-1867 i ich pozostałość aktowa, „Rocznik Łódzki”, 39 (1989). s. 27-41. 
Łupiński J., Dziekani okręgowi w diecezji wigierskiej i diecezji augustowskiej czyli sejneńskiej, „Prawo Kanoniczne”, 49 (2006) nr 1-2, s. 195-226.

Nowacki J., Archidiecezja poznańska w granicach historycznych i jej ustrój, t. 2. Dzieje archidiecezji poznańskiej, Torun 1964.

Piątkowski S., Gospodarstwo folwarczne i chłopskie w dobrach proboszczowskich Królestwa Polskiego w pierwszej połowie XIX wieku (przykład rejonu środkowej Wisły), „Studia Sandomierskie”, 10 (2003) s. 45-53.

Przybyłko M., Urząd dziekana w polskim ustawodawstwie synodalnym XVIII w., „Prawo Kanoniczne", 9 (1966) nr 1-2, s. 113-211.

Rys historyczny funduszów duchowieństwa rzymsko-katolickiego w Królestwie Polskiem, „Kronika Diecezji Kujawsko-Kaliskiej”, 9 (1915) nr 11, s. 240-242.

Rys historyczny funduszów duchowieństwa rzymsko-katolickiego w Królestwie Polskiem. Ciąg dalszy, „Kronika Diecezji Kujawsko-Kaliskiej”, 9 (1915) nr 12, s. 275279.

Skiełczyński Z., Archidiecezja warszawska w latach 1818-1830, „Studia z Historii Kościoła w Polsce", 4 (1978) s. 9-206.

Szelążek A., Podstawy dotacji duchowieństwa katolickiego w Polsce w okresie przedkonkordatowym, Toruń 1947.

Szkutnik P., Ksiądz Michał Mieczko Żdzenicki (1744-1814) proboszcz i dziekan szadkowski, „Przegląd Nauk Historycznych”, 14 (2015) s. 173-191.

\section{DEANS' SALARY IN THE KINGDOM OF POLAND UNTIL THE 1870 S. EXAMPLES}

\section{Summary}

In the Old Polish period, deans did not receive any special remuneration for the functions they performed. Dean's salary was introduced by the countries which conducted the partitions of Poland. In the nineteenth century, it became a tool for subordination of the clergy to secular authorities. Financial dependence of the church hierarchy, including deans, contributed to the fact that they became dependant on state administration. Salaries varied and depended on the size of the deanery (the number of parishes). In the first half of the nineteenth century, better-paid deans earned as much as an elementary school teacher. Nevertheless, the dean usually accumulated several prebendaries and posts which provided additional income, often many times greater than dean's salary.

Keywords: the history of the Church in Poland in the 19th century, dean, the Kingdom of Poland, the Russian Partition, salary 